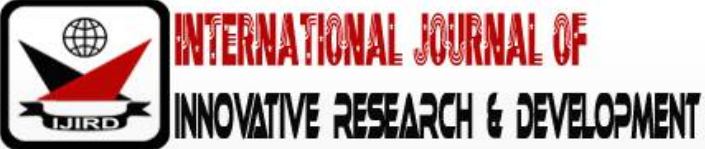

ISSN 2278 - 0211 (Online)

\section{Financing of Small and Medium Scale Enterprises and Economic Growth in Nigeria (1994-2015)}

\author{
Dr. Abolade Francis Akintola \\ Senior Lecturer, Department of Finance, Babcock University, Nigeria \\ Dr. Olusola Babatunde Oluwalaiye \\ Senior Lecturer, Department of Economics, Babcock University, Nigeria \\ Dr. Janet Arike Adegoke \\ Lecturer, Department of Business Administration, Precious Cornerstone University, Nigeria
}

\begin{abstract}
:
The reason for low performance of the industrial sector in Nigeria is mostly associated with the poor attention paid to the financing of small and medium scale enterprises which is accepted worldwide to be the engine of economic growth and development of any nation. It is for this reason; this study investigates financing of small and medium scale enterprises and economic growth in Nigeria from 1994 to 2015.

Ex-post facto research design was adopted in this study. Quantitative method was employed in this study by using Ordinary Least Square Method (OLS) as estimation technique. using multiple regression, the finding of this study was that financing of SMEs positively and significantly impact the development i.e. economic growth of Nigeria. The study therefore recommends that government should show commitment towards diversifying the economy beyond oil sector and that government should explore the advantages of SMEs to enhance economic growth in Nigeria.
\end{abstract}

Keywords: Small and medium scale enterprises, economic growth, gross domestic product, bank credit, money supply

\section{Introduction}

Small and medium scale enterprises are known worldwide as instruments of economic growth and development, this is because of their capacity to enhance the output of the economy and enhance human welfare. Small and medium scale enterprises constitute the driving force to industrial growth and development and possess great potentials in ensuring diversification and expansion of industrial production as well as the attainment of the basic objectives of development.

Small and medium scale enterprises are the backbone of successful economies like United State of America (USA) where over 23 million small businesses employ more than $50 \%$ of the private workforce and generate more than half of the national gross domestic product (Taiwo, Bako, Ajibode \& Aladelusi, 2013).

Small and medium scale enterprises (SMEs) are generally regarded as the driving force of economic growth, job creation and poverty reduction in any developing countries. They have been the means through which accelerated economic growth and rapid industrialization have been achieved (Alatise, 2012). Considerable attention has been paid by concerned authorities to the issue of poverty reduction in developing countries. It is generally agreed that the development of small and medium scale enterprises can be a key ingredient in poverty reduction. However, small and medium businesses generally suffer from a range of problems in their establishment and developments. Finance is arguably the most central. The growth of small and medium scale enterprises through effective financing options have stem debate and growing interest among researchers, policy makers and entrepreneurs, recognizing the immense contribution of the sub-sector to economic growth. Small and medium scale enterprises (SMEs) constitute the driving force of industrial growth. This is basically due to their great potential in ensuring diversification and expansion of industrial production as well as the attainment of the basic objectives of growth (Alatise,2012).

Small and medium scale industries are vital sources of employment of indigenous technology even dispersal of industrial set ups, increased production of manufacturing exports, and increasing local content of industrial output by fostering forward and backward industrial linkages to enhance the general level of economic activity. Since the Second National Development Plan (1970-1974), emphasis has been placed on the development and financing of small- scale industries for the purpose of using them as veritable engines for economic growth and development (Aremu \& Adeyemi ,2011).

Government at various levels (local, state and federal) have in one way or the other focussed on the performance of small and medium scale enterprises for economic gains. While some governments had formulated

Policies aimed at facilitating and empowering the growth and development and performance of the SMEs, others had focussed on assisting the SMEs to grow through soft loans and other fiscal incentives in order to enhance the socio- 
economic growth of the economy like alleviating poverty , employment generation, enhance human development , and improve social welfare of the people (Akingunola,2011).

Many countries across the globe initiated several policies for small and medium scale sub-sector. Nigeria also recognized the need to embark on rapid economic and sustainable development, which led to a number of policies for the support and promotion of small and medium scale enterprises. In spite of the implementation of the policies which included financial, institutional, capacity building, technology acquisition, business promotion, export promotion and tax relieves among others for more than three decades, the SMEs sub-sector contributes less than $10 \%$ to the nation's gross domestic product (GDP) (SMEDAN,2006).

Access to institutional finance has been a problem for SMEs development in Nigeria, in the past, a number of policies has been put in place to provide special credit lines for SMEs, but this achieved very limited impact for various reasons. It is for what we have discussed above that this paper investigates 'financing of small and medium scale enterprises and economic growth in Nigeria from 1994 to 2015'.

\section{Literature Review}

\subsection{Conceptual Framework}

In a global context, a general definition of SMEs using size and scale of operations is not easy, but within the fixed co-ordinates of national boundaries, it might be relatively easier. At the $13^{\text {th }}$ Council meeting of the National Council on Industry held in July,2001, Micro Small and Medium Enterprises (MSMEs) were defined by the Council as follows:

- Micro / Cottage Industry: micro /cottage industry is one with a labour size of not more than 10 workers, or total

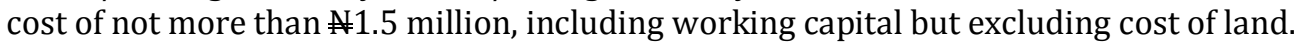

- Small- Scale Industry: This is an industry with a labour size of 11-100 workers or a total cost of not more than N50million, including working capital but excluding cost of land.

- Medium Scale Industry: a medium scale industry is an industry with a labour size of between $101-300$ workers or a total cost of over N50million but not more than $\$ 200$ million, including working capital but excluding cost of land.

- Large Scale Industry: A large scale industry is one with a labour size of over 300 workers or a total cost of over N200 million, including working capital but excluding cost of land (Alatise,2012). According to Schaper (2002), SMEs account for over $95 \%$ of private sector firms in most industrialized economies.

\subsection{Theoretical Framework}

\subsubsection{Grameen Model}

In the Grameen model, a group of five (5) members of a unit organise applied for a loan to finance their business. In the first round, the loan is granted to two members to invest in their business. If these two members became successful in repaying the amount loaned to them,then, in the next four to six weeks later, the next two members are granted the loan. Last one member would be eligible for a loan if the previous two repay their loan successfully.Repayment of open loan door for the next loan and then go on if all members repay loan successfully. If anyone of the group member defaulted in the loan repayment, the whole group would be disqualified for a further loan. With this, rather to financial collateral, social collateral is involved.

\subsubsection{The Stakeholder and Competitive Value Approaches}

The father of the stakeholder theory is Freeman Edward. The basis for performance under these approaches is the ability of the organization to meet the needs and expectations of external stakeholders (individual or group who can affect or is affected by the firm's achievement of its objectives) such as competitors, financiers, employees, government bodies , owners , the community , customers ,trade unions and suppliers (Ariyo,2007). The stakeholder point of view of the firm entails the general explanation of sustainable improvement which takes into outstanding consideration the assignment of a pleasant the necessities of a firm's stakeholders with the void of compromising the firm's potential to fulfil the necessities of future stakeholders. The stakeholder and competitive cost techniques are long-term tools and are concerned with meeting the expectations as nicely as the wishes of external stakeholders. The stakeholder principle dwells on the priority of exterior stakeholder, whilst aggressive approach dwells oneffectiveness, efficiencies and flexibility of the corporation in the usage of assets to meet up with the external pressures.

\subsection{Empirical Review}

UNIDO (1992) in a study of the importance of infrastructure in SMEs development concluded that unless needed infrastructures are available to support SMEs industrial development and growth will be minimal.

Ukpong (1992), identified lack of information on credits, incentives, lack of credit guarantee and lack of collaterals as major constraints in the policy and business environment of the SMEs. He also established that banks give lesspriority to SMEs incredit advancement through imposing stringent conditions. Agyei-Mensah (2011) explored the relationship between working capital and capital budgeting decisions have been made in small firms and to identify the problems they face with regard to taking suchdecisions. The study has shown that the three most influential factors that did motivate the sample firms in pursuing sound financial management practices were: pressure from bankers, pressure from external accountants and pressure from providers of capital. Hence, the study recommended that small firms should disclose fully the financial position by keeping full set of information on their business transactions. 
Fatoki (2012) conducted a survey on financial management practices of new micro enterprises in South Africa. He focussed on financial planning and control, financial analysis, accounting information, management accounting, investment appraisal and working capital management. From the study, it was concluded that financial management practices of micro enterprises are very weak and in areas of financial planning, analysis and control and investment decisions. Hence, the study suggested that training should be given in the areas of financial management, e-accounting and the evaluation of investment decisions.

Abanis (2013) carried out a study to determine the extent of financial management practices in small and medium enterprises (SMEs) in selected district in Western Uganda. The objective of the study was to determine the extent of financial management employed by SMEs as to the dimensions: working capital management, investment, financing, financial reporting and analysis and accounting information systems. The study found out that the extent of financial management is low among SMEs.

Lakew and Rao (2013) investigated the effect of financial management practices and financial characteristics on profitability of business enterprises in the Jimma town of Ethiopia. They pointed out that efficiency of financial practices and characteristics can bring higher profitability.

\section{Methodology}

The main objective of this study is to evaluate financing of small and medium scale enterprises on economic growth in Nigeria. To achieve this objective, research design adopted in this study isex-postfacto. This is because the event has already taken place. The annual time series data were collected from secondary source from 1994 to 2015 . The data were collected from Central Bank of Nigeria statistical bulletin.

\subsection{Data Presentation and Analysis}

In view of the nature of this research study, quantitative method was employed in this study. The study employed the Ordinary Least Square method (OLS) as the estimation technique through stepwise regression to avoid multi- co linearity of explanatory variables. With the aid of E-view software, the model will be estimated using annual data from 1994 to 2015.

\subsection{Model Specification}

Our model traces the effect of finance small and medium scale enterprises on economic growth in Nigeria over time and takes into consideration a growth model.

Gross domestic product will be the dependent variable. This is because a change in finance of small and medium scale enterprises, supply of money etc are expected to have an effect on gross domestic product (GDP).

Our functional form: $\mathrm{GDPg}=\mathrm{f}(\mathrm{SMEF}, \mathrm{MS}, \mathrm{CPS}, \mathrm{INT})$

Mathematical model

$\mathrm{GDP}=\beta_{0}+\beta_{1} \mathrm{SMEF}+\beta_{2} \mathrm{MS}+\beta_{3} \mathrm{CPS}+\beta_{4} \mathrm{INT}+\mu$

Econometric model

In GDP $=\beta_{0}+\beta_{1}$ SMEF $+\beta_{2}$ MS $+\beta_{3}$ CPS $+\beta_{4}$ INT $+\mu$

Definition of Terms

$\mathrm{GDPg}=\mathrm{GDP}$ growth rate

$\mathrm{SMEF}=\mathrm{SMEs}$ financed measured as bank credit to SMEs as \% of GDP

$\mathrm{MS}=$ is broad money supply, measured as \% of GDP

$\mathrm{CPS}=$ Credit to private sector, measured as \% of GDP

INT = interest rate measured as \% of GDP

$\mu=$ Stochastic Error Term

$\beta_{0}$ is the intercept of relationship in the model/ constant

$\beta_{1}, \beta_{2}, \beta_{3}, \beta_{4}$ are coefficient of each of the independent variables

\section{Data Analysis and Interpretation}

The data used in the analysis include the gross domestic product (GDP),SME Finance (SME), money supply (M2), Credit to private sector (CPS), interest rate (INT) all in naira.

The table below presents the data from the period 1994 to 2015 used for the study.

\begin{tabular}{|c|c|c|c|c|c|}
\hline Year & GDP & SME Finance & M2 & CPS & $\begin{array}{c}\text { Interest } \\
\text { Rate }\end{array}$ \\
\hline 1994 & $545,672.41$ & N/A & $75,401.18$ & $41,352.46$ & 20.01 \\
\hline 1995 & $875,342.52$ & $20,400.0$ & $111,112.31$ & $58,122.95$ & 29.80 \\
\hline 1996 & $1,089679.72$ & $15,462.9$ & $165,338.75$ & $127,117.71$ & 18.32 \\
\hline 1997 & $1,399,703.22$ & $20,552.5$ & $230,292.60$ & $143,424.21$ & 21.00 \\
\hline 1998 & $2,907,358.18$ & $32,374.5$ & $289,091.07$ & $180,004.76$ & 20.18 \\
\hline 1999 & $4,032,300.34$ & $42,302.1$ & $345,853.96$ & $238,596.56$ & 19,74 \\
\hline 2000 & $4,189,249.77$ & $40,844.3$ & $413,280.13$ & $316,207.08$ & 13.54 \\
\hline 2001 & $3,989,450.28$ & $42,260.7$ & $488,145.79$ & $351,956.19$ & 18.29 \\
\hline 2002 & $4,679,212.05$ & $46,824.0$ & $628,952.16$ & $431,168.36$ & 21.32 \\
\hline
\end{tabular}




\begin{tabular}{|c|c|c|c|c|c|}
\hline Year & Gdp & Sme Finance & M2 & Cps & Interest Rate \\
\hline 2003 & $6,713,574.84$ & $44,542.3$ & $878,457.27$ & $530,373.30$ & 17.98 \\
\hline 2004 & $6,895,198.33$ & $52,428.4$ & $1,269,321.61$ & $764,961.52$ & 18.29 \\
\hline 2005 & $7,795,758.35$ & $82,368.4$ & $1,505,963.50$ & $930,493.93$ & 24.85 \\
\hline 2006 & $9,913,518.19$ & $90,176.5$ & $1,952,921.19$ & $1,096,535.57$ & 20.71 \\
\hline 2007 & $11,411,066.91$ & $54,981.2$ & $2,131,818.98$ & $1,421,664.03$ & 19.18 \\
\hline 2008 & $14,610,881.45$ & $50,672.6$ & $2,637,912.73$ & $1,838,389.93$ & 17.95 \\
\hline 2009 & $18,564,594.73$ & $25,713.7$ & $3,797,908.98$ & $2,290,617.76$ & 17.26 \\
\hline 2010 & $20,657,317.67$ & $41,100.4$ & $5,127,400.70$ & $3,668,657.82$ & 16.94 \\
\hline 2011 & $24,296,329.29$ & $13,512.2$ & $8,008,203.95$ & $6,920,498.75$ & 15.14 \\
\hline 2012 & $24,794,238.66$ & $16,366.5$ & $9,411,112.25$ & $9,102,049.11$ & 18.99 \\
\hline 2013 & $33,984,754.13$ & $12,550.3$ & $11,034,940.93$ & $10,157,021.18$ & 17.59 \\
\hline 2014 & $37,409,860.61$ & $15,611.7$ & $12,172,490.28$ & $10,660,071.84$ & 16.02 \\
\hline 2015 & $40,544,099.94$ & $13,863.5$ & $13,895,389.13$ & $14,649,276.46$ & 16.51 \\
\hline
\end{tabular}

Table 1

Source: CBN Statistical Bulletin

\subsection{Analysis of Table One}

From the year 1995 to 2003, SME finance decreased slightly then increased steadily from 1997 at $20,552.5$ to $44,542.3$ in2003. From then onwards to the year 2015 it showed marginal fluctuations and it eventually fell to13,863.5 in the year 2000. There was an interesting turn of event in Nigeria's exchange rate regime within this period. The naira also depreciated steadily from 9.9095 in 1994 to 22.0511 in 1996 . However, the naira remained constant from 1997 to 2001 at 21.8861 per dollar before increasing from 92.6934 in 2002 to 102.1052 in the year 2003. Tariff showed a continuous steady increase from $11,456.9$ million naira in 1994 to $37,364.0$ million naira in 1998 . It fluctuated marginally from 1999 until it climaxed at 101,500 million naira in the year 2003. Trade openness also showed a steady marginal decrease from 1994 to 1997 from 0.676055 to 0.409893 respectively.

Interest rate on the other hand showed a high rate of fluctuation within 1994 to 2000 and it reached its highest rate 29.0 percent in1995. Interest rate increased from 18.29 percent in 2004 to 24.4 percent in 2005 but it declined marginally from 2006 to 2011 from 20.48 to 15.14 percent respectively. It increased briefly to 18,36 percent in 2012 but the increase was short live. Because it further showed a marginal decrease to 18.05 percent in 2014.

\subsection{Unit Roots Test}

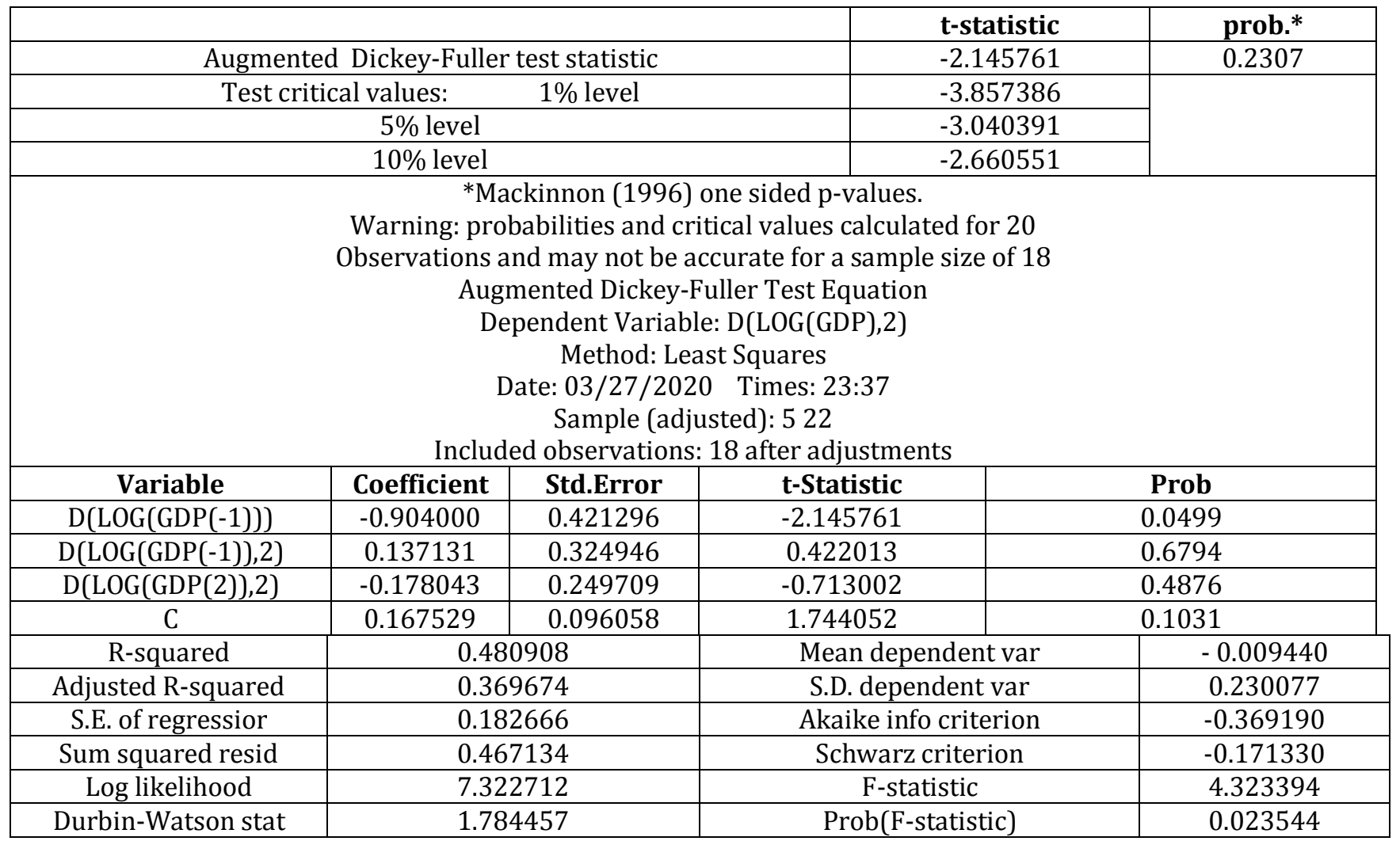

Table 2: Null hypothesis is: D (LOG(GDP)) has a unit root

Exogenous: constant

Lag Length: 2(Automatic based on SIC, MAXLAG=4)

Source: Authors' Computation 
From studies and researches, time series data are hardly stationary (non-stationary) and using non- stationary variable in the model will lead to spurious regression, which when use to forecast or predict may give an inaccurate prediction. Hence, the first step is to examine the characteristics of the data in order to determine whether the variable have unit roots i.e., whether it is stationary and the order of integration . For this purpose, the Augmented Dikey- Fuller test is used. If the ADF test < Mackinnon critical values, we conclude that, there is no unit root and thusreject the null hypothesis (Ho) and vice versa. The result of the stationary test with trend and intercept is presented in Table two below.

From the result, it is observed that the variables are non-stationary at their original level and therefore the need to difference the time series data $\log$ (GDP) is stationary at its $1^{\text {st }}$ difference. The ADF test for GDP (-2.145761) $<$ MacKinnon critical value at $1 \%, 5 \%$, and $10 \%(-3.857386,-3.040391,-2.660551)$ thus, we conclude that the GDP data is stationery at its $1^{\text {st }}$ difference.

\subsection{The Model}

The relationship between the variables is transformed and expressed in mathematical notation for empirical verification. The model is as follows:

$\mathrm{GDP}=\beta_{0}+\beta_{1} \mathrm{SMEF}+\beta_{2} \mathrm{M} 2+\beta_{3} \mathrm{CPS}+\beta_{4} \mathrm{INT}+\mu$

Where:

GDP=Gross domestic product

$\mathrm{SMEF}=$ small and medium enterprise finance

M2=money supply

$\mathrm{CPS}=$ credit to private sector

INT= interest rate

$\mu=$ Error term

\section{Regression Output (E-View)}

\begin{tabular}{|c|c|c|c|c|}
\hline Variable & Coefficient & Std. Error & t-Statistic & Prob. \\
\hline C & 2.815447 & 0.939361 & 2.997195 & 0.0085 \\
\hline LOG(SME_FINANCE) & 0.293810 & 0.128551 & 2.285559 & 0.0363 \\
\hline M2 & $4.05 E 09$ & $3.91 \mathrm{E} 08$ & 0.103533 & 0.9188 \\
\hline LOG(CPS) & 0.725793 & 0.087463 & 8.298248 & 0.000 \\
\hline DLOG(INTEREST_RATE & 0.139262 & 0.201328 & 0.691716 & 0.4990 \\
\hline R-squared & 0.979028 & Mean Dependent var & 15.89214 \\
\hline Adjusted R-squared & 0.973785 & S.D. dependent var & 1.149099 \\
\hline S.E. of regression & 0.186050 & Akaike info criterion & -0.321343 \\
\hline Sum of squared resid & 0.553835 & \multicolumn{2}{|c|}{ Schwarz criterion } & -0.072647 \\
\hline Log likelihood & 8.374103 & \multicolumn{2}{|c|}{ Prob(F-statistic } & 186.7322 \\
\hline Durbin-Watson stat & 1.558423 & \multicolumn{2}{c|}{0.000000} \\
\hline
\end{tabular}

Table 3: Dependent Variable: LOG (GDP)

Method: Least Squares

Date: 27/03/2020 Time: 23:13

Sample (Adjusted): 222

Included Observations: 21 after Adjustments

Source: Author's Computation

\subsection{Result of the Regression Analysis}

$\begin{array}{ll}\text { LOG(GDP) } & =2.815447+0.293810 \text { LOG(SMEF) + 4.05E09 (M2) + 0.725793 LOG(CPS) + 0.139262 DLOG(INT) } \\ \mathrm{SE} & =(0.939361)(0.128551)(3.91 \mathrm{E} 08)(0.087463)(0.201328) \\ \mathrm{t}-\mathrm{Stat} & =(2.997195)(2.285559)(0.103533)(8.298248)(0.691716) \\ \text { Prob } & =(0.0085)(0.0363)(0.9188)(0.0000)(0.4990) \\ \mathrm{R}^{2} & =0.979028 \\ \text { Adjusted } \mathrm{R}^{2} & =0.973785 \\ \mathrm{~F}_{\text {stat }} & =186.7322 \\ \mathrm{~F}_{\text {prob }} & =0.000000\end{array}$

Durbin-Watson stat $=1.558423$

\subsection{Statistical Criteria}

The $\beta_{0}$ coefficient 2.815447 shows the amount of gross domestic product (GDP) will be if the explanatory variable is zero. The probability value of the variable is 0.0085 , which state that the model is good.

The coefficient of SME Finance (SMEF), money supply (M2), credit to private sector (CPS), interest rate (INT), ( $\beta_{1}, \beta_{2}, \beta_{3}$, $\beta_{4}$ ), with corresponding probability value that state that the model is also good. 


\subsection{R2 (Coefficient of Determination)}

The R2 (Coefficient of determination) is 0.979028 showing that the explanatory variable explains $97 \%$ changes in the dependent variable. This is however a good relationship between these variables. The contribution of other factor is captured in the error term $(\mu)$.

\subsection{Tests of Significance}

\subsubsection{T-Test}

HO: $\beta_{1}=0$ Reject

H1: $\beta_{1} \neq 0$ Accept

Test for $\beta_{1}$

$\mathrm{T}^{*}=2.285559$

At $5 \%$ level of significance, $0.05 / 2=0.025$

Degree of freedom $=\mathrm{n}-\mathrm{k}=20 ; \mathrm{n}=22 ; \mathrm{k}=2 . \mathrm{Tt}=2.086$

\subsubsection{Decision Rule}

From our value the $t^{*}=2.285559>t_{t}=2.086$, hence we accept $H_{1}$ meaning that the estimate of the parameter $\beta_{1}$, $\beta_{2}, \beta_{3}, \beta_{4}$ (SMEF, M2, CPS, INT) is statistically significant in explaining the variability in the dependent variable (GDP). From the series of test conducted, the outcome of findings shows that there is a positive relationship between dependent variable and the independent variables.

\section{Conclusion}

This study examines financing of small and medium scale enterprises and economic growth inNigeria.The study observed that the factors that influence economic growth anddevelopment such as financing private enterprises represented by credit to private sector, monetary policy of government and interest rate are examined. Using multiple regression, it was observed that financing of SMEs significantly impacts the development of Nigeria. The study showed that one percent increase in SME financing leads to 29.4 percent growth in GDP, one percent increase in credit to private sector as a whole contributes 72.6 percent increase in GDP. Banks loans and advances to SMEs is not only limited but have been dwindling over the years and the SMEs cannot raise their fund from savings as a result of highly skewed income distribution that kept operators impoverished. Unemployment rate in Nigeria is still very high and one realistic way of reducing it is to empower the SMEs financially.

\section{Recommendations}

Considering the importance of SMEs to the economy in areas of creating jobs, entrepreneurship, poverty alleviation, wealth creation as well as increasing a nation's gross domestic product (GDP), the following recommendations are made:

There is urgent need to show commitment towards diversifying the economy beyond the oil sector. We should explore the advantages of SMEs to enhance economic growth.

There is an urgent need for the government toprovide an enabling environment in the form of efficient and available basic infrastructural facilities especially electricity and roads.

Government should encourage small and medium scale enterprises by giving them incentives, instructing banks to lend out to the enterprises at low interest rate and tax allowance should be given them on initial capital outlay and plants and machineries.

Finally, federal government should set up an agency funds accessible to small and medium scale enterprises e.g. National Credit Guarantee Schemes for SMEs.

\section{References}

i. Abanis, T. (2013). Financial management practices in small and medium enterprises in selected districts in Western Uganda. Research Journal of Finance and Accounting, 4 (2), 29- 42.

ii. Adelaja, B, O. (2003). Financing small and medium enterprises under SMIEIS: Operators' perspectives: Seminar on Small and Medium Industries Equity Investment Scheme (SMIEIS). Central Bank of Nigeria, Publication of CBN.

iii. Agyei- Mensah, B. (2011). Financial management practices of small firms in Ghana: An empirical study. African Journal of Business Management, 5 (10), 3781- 3793.

iv. Akingunola, R. O. (2011). Small and medium scale enterprises (SMEs) and economic growth in Nigeria: An assessment of financing options and prospects. PhD Thesis at The St. Clements University.

v. Alatise, I. (2012). Financing small and medium scale enterprises as catalyst for economic development in a democratic consolidation. Proceedings of 2012 National Conference on National Security and Economic Development for Democratic Consolidation, Lagos State Polytechnic, 171- 181.

vi. Aremu, M. A. \& Adeyemi, S. L. (2011). Small and medium scale enterprises as a survival strategy for employment generation in Nigeria. Journal of Sustainable Development Vol 4 (1), 200- 206.

vii. Ariyo,D. (2007). Small firms are the backbone of Nigeria economy: Africa Economy Analysis. Africa Business Information Service, Bridgnorth United Kingdom. 
viii. Fatoki, 0. (2012). An investigation into the financial management practices of new micro- enterprises in South Africa. Journal of Social Science, 33(2), 179-188.

ix. Lakew, D. \& Rao, P. (2013). Effect of financial management practices and characteristics on profitability. A study on business enterprises in Jimma town, Ethiopia. Journal of Research in Commerce and Management, 2 (5), 64 75.

x. Schaper, M. (2002). Small firms and environmental management. International Small Business Journal Vol 20 (3), $235-251$.

xi. SMEDAN (2006). National policy on small medium and micro enterprises. Small and Medium Development Agency of Nigeria,Abuja.

xii. Taiwo, A. Bako, Y. Ajibade, F. B. \& Aladelusi, K. B. (2013).Entrepreneurship education: A panacea to youth unemployment. $8^{\text {th }}$ National Conference on Sustainable Development, The Federal Polytechnic , Ilaro ,77 -82 .

xiii. UNIDO (1992). Guidelines for the establishment of industrial estates in developing countries. United Nations Industrial Development Organization, New York.

xiv. Ukpong, C. G. (1992) A review of small-scale credit delivery in Nigeria.CBN Economic and Financial Review Journal Vol 3(4). 